TECHNICAL NOTES AND MANUALS

\title{
The Case for Depositor Preference
}

Marc Dobler, Ender Emre, Alessandro Gullo and Deeksha Kale

Monetary and Capital Markets and Legal Departments

I NTERNATIONAL MONETARY FUND 
TECHNICAL NOTES AND MANUALS

The Case for Depositor Preference

Marc Dobler, Ender Ere, Alessandro Gull and Deeksha Kale

Monetary and Capital Markets and Legal Departments

IN TER NA TI ON AL MONETARY FUN D

CInternational Monetary Fund. Not for Redistribution 
INTERNATIONAL MONETARY FUND

Monetary and Capital Markets Department and Legal Department

\section{The Case for Depositor Preference}

Prepared by Marc Dobler, Ender Emre, Alessandro Gullo, and Deeksha Kale

Authorized for distribution by Tobias Adrian and Rhoda Weeks-Brown

December 2020

DISCLAIMER: This Technical Guidance Note should not be reported as representing the views of the IMF. The views expressed in this paper are those of the authors and do not necessarily represent the views of the IMF, its Executive Board, or IMF management.

\begin{tabular}{|ll|}
\hline JEL Classification Numbers: & G1, G18, G21, G33 \\
\hline Keywords: & Depositor Preference, Deposit Insurance, Bank, Creditor Hierarchy \\
\hline Authors' E-Mail Addresses: & mdobler@IMF.org \\
& eemre@IMF.org \\
& agullo@IMF.org \\
& dkale@IMF.org \\
\hline
\end{tabular}




\section{TECHNICAL NOTES AND MANUALS}

\section{The Case for Depositor Preference}

Prepared by Marc Dobler, Ender Emre, Alessandro Gullo and Deeksha Kale

This technical note and manual (TNM) addresses the following issues:

- Advantages and disadvantages of different types of depositor preference.

- International best practice and experience in adopting depositor preference.

- Introducing depositor preference in jurisdictions with or without deposit insurance. 


\section{CONTENTS}

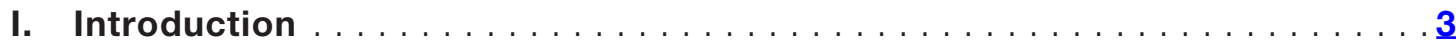

II. Context and Principles for Depositor Preference $\ldots \ldots \ldots \ldots \ldots \ldots \ldots$

III. Forms of Depositor Preference $\ldots \ldots \ldots \ldots \ldots \ldots \ldots \ldots \ldots \ldots \ldots \ldots$

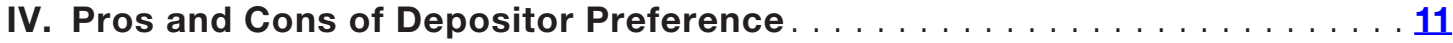

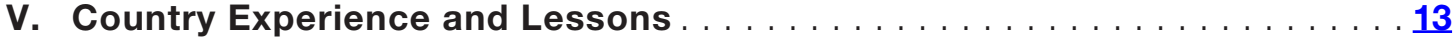

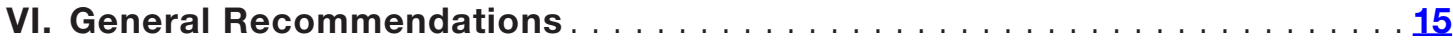

Appendix 1. The Evolution of Senior Debt-Deposit Spread Following the Introduction of Depositor Preference in the European Union . . . . . . . 17 


\section{INTRODUCTION1}

There are compelling grounds to give a priority to deposits, compared to other senior unsecured $^{2}$ claims. The hierarchy of creditor claims applicable in bank insolvency establishes the order in which creditors should be paid from the assets of a failed bank. ${ }^{3}$ In some jurisdictions, deposit liabilities rank equally (or "pari passu") with other general unsecured claims. With depositor preference, deposit liabilities are given a more senior (or higher) position than other senior unsecured creditor claims. As such, they must be paid in full before other general unsecured claims could be met, increasing the chances of recoveries from a failed bank's assets. By increasing the depositors' recoveries, it may reduce the costs of protecting deposits in a deposit insurance payout (in jurisdictions with deposit insurance), or in a bank resolution in which the government has to protect depositors to preserve financial stability (in jurisdictions without deposit insurance). As such, depositor preference enhances a country's financial safety net. ${ }^{4}$

This note takes stock of the different types of depositor preference, offers a framework for assessing their relative advantages and disadvantages, and makes policy recommendations. Section II will explain the context and principles for depositor preference. Section III will provide an overview of different forms of depositor preference, followed by a discussion in Section IV on their relative advantages and disadvantages. Section V includes a cross-jurisdictional analysis of depositor preference regimes. The last section draws conclusions.

1 This note has benefited from comments and contributions from Tobias Adrian, Jose Garrido, Deniz Igan, Yan Liu, Maike B. Luedersen, Marina Moretti, Jan Nolte, David Parker, Alvaro Piris, and Miguel Savastano.

2 The term "senior" unsecured creditors is widely used in finance to denominate "general" (not subordinated) unsecured creditors, and these terms are used synonymously in this technical note.

3 The term "insolvency" can be used interchangeably with liquidation, depending on the nomenclature and legal tradition in different jurisdictions.

4 The financial safety net consists of early intervention powers of the bank supervisor, lender-of-last-resort funding from the central bank, deposit insurance, the bank resolution regime, and arrangements for crisis coordination. 


\section{CONTEXT AND PRINCIPLES FOR DEPOSITOR PREFERENCE}

Insolvency laws determine the order of loss allocation between creditors based on the different attributes of certain claims and public policy goals. While equality among creditors is a general principle (Box 1), absolute equality in loss allocation would be inequitable where the legal and economic nature of certain claims significantly differ from others. When establishing the order in which debtor claims will be satisfied from the proceeds of an insolvent firm, insolvency laws may give priority to certain categories of claims (e.g., secured claims) or may create sub-ranks within a particular category (e.g., subordination). Jurisdictions may also protect certain interests in view of public policy objectives. Priorities given in the law to tax claims, employee claims, and the costs of insolvency administration arise from such public policy considerations.

\section{BOX 1. General Principles for Creditor Hierarchies}

The following principles should be considered when establishing a bank creditor hierarchy:

- Equality. In principle, creditors should be treated pari passu, unless there are fundamental differences in the legal and economic nature of their relationship with the bank or compelling public interest reasons for distinguishing between them. Introducing a multitude of creditor classes may undermine the efficiency of insolvency proceedings or resolution regimes.

- Necessity. The ranking of depositors claims in the creditor hierarchy should be determined to best serve a jurisdiction's public policy objectives, including enhancing financial stability, as well as reducing resolution costs to the Deposit Insurance Scheme (DIS), and the public more broadly (e.g., in jurisdictions without a DIS or where the government provides a backstop to the scheme).

- Transparency. The creditor hierarchy should be set out clearly and transparently, in the bank liquidation or resolution law. In case the general insolvency law applies to bank liquidation, it is recommended to modify this creditor hierarchy through clear bankspecific provisions, either in the banking law or in the general insolvency law.

- Consistency. The order of allocation of losses to creditors-including to the DIS-in resolution versus liquidation should not differ materially. Significant divergences between creditor treatment in resolution and liquidation, for instance as a result of statutory and discretionary exclusion of certain claims from bail in, increase the risk of legal challenges and compensation claims (Figure 1). For this reason, the 2014 revisions to the IADI's Core Principles for Effective Deposit Insurance Systems included a new principle that recommends resolution procedures follow a defined creditor hierarchy in which insured deposits are protected from sharing losses. 
Distinct legal features of bank deposits justify their preferential treatment. Jurisdictions typically qualify bank deposits as a loan, or a form of safekeeping contract, with provisions allowing the use of deposited money, or a mix of these two types of contracts. ${ }^{5}$ With a typical deposit, the bank: (i) acquires the ownership title to the deposited money; (ii) can use the money; (iii) may pay little (or no, for example, in the case of demand deposits) interest; and (iv) should fulfill its repayment obligation on demand, or upon maturity for term deposits. Banks also enjoy a legally protected exclusivity to collect deposits. Finally, while wholesale creditors would generally be in a position to assess bank risk and loss allocation rules when extending credit, retail depositors are not well placed to assess their risks arising from the insolvency of a bank (nor can they mitigate such risks by securing collateral). They would need to be able to discern bank asset quality, either directly from reviewing individual bank returns, or from third party reports (e.g., credit rating agencies). The costs associated with developing the expertise to do this would be disproportionately high compared to the low value sums typically placed by retail depositors. Deposit preference, and also deposit insurance, obviate this need and increase the acceptance of deposits as 'bank created money.'

Public policy objectives also justify a preferential treatment of deposits. Bank supervision and the provision of lender-of-last-resort funding (to solvent and viable banks) reduce the likelihood of failure but cannot prevent it. ${ }^{7}$ Bank resolution regimes and DIS deal with the impact of failure and attribute losses to specific creditors. The way in which resolution powers can attribute losses is linked closely to the loss-allocation rules under insolvency, as well as the public policy objectives of resolution (including preserving financial stability and continuity of critical financial services, minimizing the costs of failure etc.):

- Facilitating effective resolution: Corporate insolvency frameworks include safeguards in order for a reorganization plan to bind dissenting creditors. ${ }^{8}$ Bank resolution frameworks include similar safeguards, as resolution entails loss allocation (which can diverge from that in liquidation) without creditor consent. Assuming that, absent resolution, the bank would have been placed in liquidation, the insolvency ranking provides a yardstick for allocating losses in resolution. Specifically, the general principle of pari passu treatment of creditors of the same class should be observed in resolution, with flexibility to depart only, if necessary, to contain the potential systemic impact of a bank's failure (or to maximize the benefit for all creditors). Resolution powers may protect certain creditors (such as retail depositors to preserve financial stability), making them potentially better off than they would have been in liquidation. This can be defended as long as other creditors receive no less than they would have received in liquidation, ${ }^{9}$ giving rise to the "no creditor worse off than in liquidation" (NCWOL) safeguard. With a depositor preference, deposit claims would not incur losses pari passu with other unsecured creditors during liquidation. This also facilitates the distinguished treatment of deposits during resolution without the risk of breaching the NCWOL safeguard. ${ }^{10}$ Figure 1 provides an example of the risks that would arise in resolution were retail deposits protected, to the disadvantage of other creditors, without depositor preference.

5 See Geva and Benjamin (2001); and Laurinavicius (2006) on the legal nature of bank deposits in various jurisdictions.

6 See Dang et al (2017).

7 Not only depositors, but all creditors may benefit from the existence of the financial safety net.

8 UNCITRAL (2005).

9 See Marino et al (1999) on the history of the Federal Deposit Insurance Corporation adopting this approach prior to the introduction of depositor preference in the United States.

10 Lenihan, Luedersen, and Schulte (2016). 
- Protecting the payment system and economic activity. The deposits of individuals and nonfinancial firms are often a means of payment rather than financial investments, including working capital of firms paying wages and suppliers. By providing preferential treatment, depositor preference may facilitate access to deposits both during resolution and liquidation and help insulate the payment system and mitigate the wider economic impact of bank failures.

- Reducing the cost of protecting depositors in liquidation or resolution. Depositor preference is distinct from deposit insurance and may be introduced in jurisdictions that have, and do not have, a deposit insurance system (DIS). In jurisdictions with DIS - the preferential treatment of deposits and the DIS subrogated ${ }^{11}$ in the place of insured deposits-reduces the costs to the DIS of liquidation and depositor reimbursement, as well as the amount the DIS would need to contribute to support the transfer of deposits in a bank resolution. As such, it can buttress depositor confidence in the DIS by enabling it to better fulfill its deposit insurance mandate for any given level of funding. Depositor preference would also help reduce taxpayers' costs in a resolution where the state, in place of, or in the absence of, a DIS in a systemic crisis ${ }^{12}$ protected depositors. Hence, even in countries without an established DIS, depositor preference can help provide a minimum level of protection to retail depositors and mitigate contingent fiscal risks.

11 The substitution of the claims of one party (e.g. an insured depositor) for those of another party (e.g. the DIS). The subrogation rights of a DIS are typically prescribed specifically in the law.

12 Deposit insurance funds are typically calibrated to cover losses at a fraction of the insured pool of deposit takers and not to deal with the failure of a large systemic bank or a generalized banking crisis.

Technical Notes and Manuals 2020/002

\section{(C)International Monetary Fund. Not for Redistribution}




\section{FIGURE 1. Litigation/Compensation Risks if Creditor Treatment in Resolution Diverges from the Creditor Hierarchy (in U.S. dollars)}

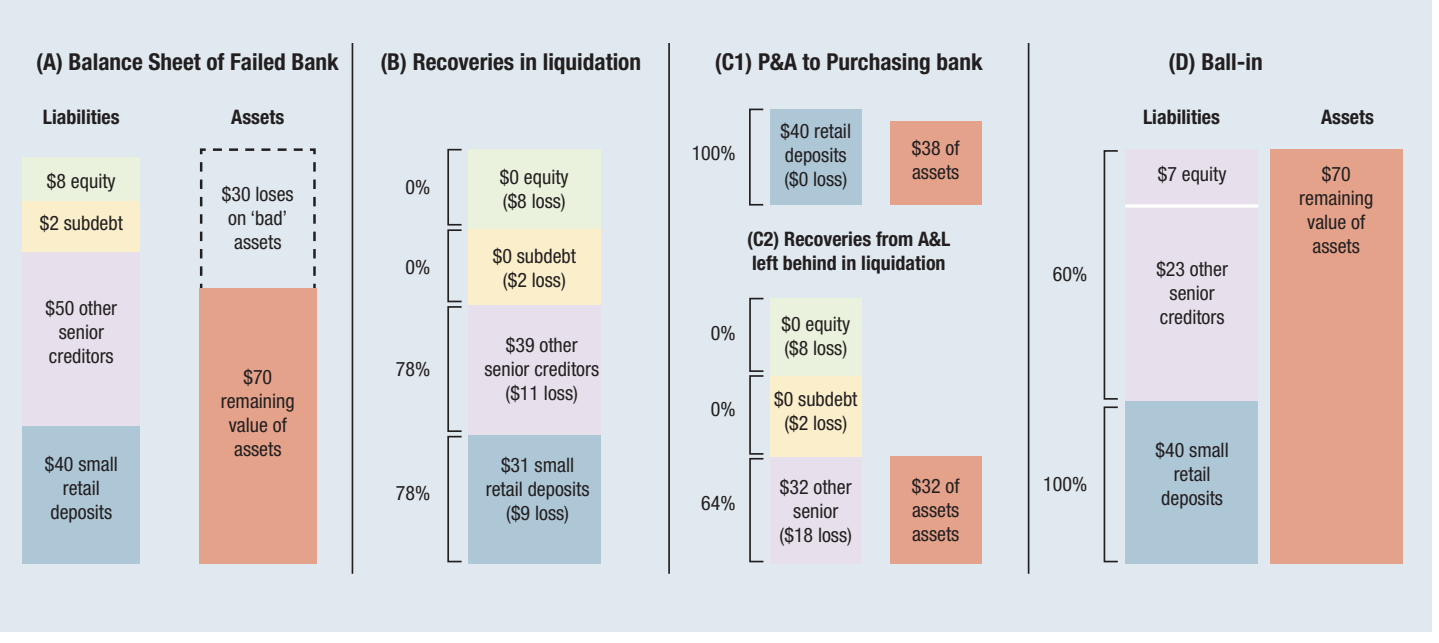

Source: Adapted from Davies and Dobler (2011)

The example shows how a purchase and assumption (P\&A, see panels C) or bail-in (panel D) could disadvantage other creditors (giving them grounds to seek compensation/litigate) if retail deposits are protected in a bank resolution but would rank pari passu with wholesale/ other senior unsecured creditors in insolvency. Panel A shows a simple balance sheet of a bank which is insolvent due to a US $\$ 30$ loss on assets. Panel B shows estimated creditor recoveries (in percentages) in a whole bank liquidation assuming no liquidation costs (it should be noted that these costs would typically be high, reducing recoveries). Panels $\mathrm{C}$ and $\mathrm{D}$ show recoveries if resolution powers were instead used to effect a $\mathrm{P} \& \mathrm{~A}$ or bail-in respectively, and retail deposits had to be fully protected to mitigate the risk of depositor contagion. Both resolutions give rise to litigation risk and potential creditor compensation claims, as the other senior creditors were made worse off than in liquidation.

P\&A: Panel C.1 assumes that the purchaser accepts US $\$ 2$ more of liabilities than assets in the P\&A with the difference constituting a premium for acquiring deposits (acquiring deposits typically carries costs for banks hence they may pay a premium). Equity, subordinated debt and wholesale deposits, together with remaining assets, are left behind and liquidated. If the bank's US $\$ 100$ book value of assets were worth only US $\$ 70$ in insolvency, the percentages represent the net recoveries as a proportion of original creditor claims. Wholesale creditors incur an extra loss of US\$7 compared to liquidation. In the latter they would have had an equal claim (with depositors) over the US\$70 value of the assets and would have received US\$39 instead of US\$32 after the P\&A.

Bail: in: In panel D, bail-in powers are used to write down to zero equity and subordinated creditors, write down a portion of wholesale creditors' claims and convert a further portion of their claim into equity without imposing losses on depositors. Wholesale creditors incur an extra loss of US\$9, compared to their losses in insolvency. 


\section{FORMS OF DEPOSITOR PREFERENCE}

While the specific details of depositor preference vary across countries, it is useful to consider three common types (Box 2). These types are informed by the structure of financial system, institutional set up, and broader legal framework.

- Insured depositor preference provides preferential treatment for insured deposits-those deposits that are eligible and within the specified deposit insurance limit—over other ordinary, senior (non-subordinated) unsecured creditors (e.g., bondholders, interbank deposits). ${ }^{13}$ The DIS would normally be subrogated to insured depositor claims to the extent of any deposit insurance payouts. The uninsured amount of an "eligible" deposit (i.e., a deposit eligible for deposit insurance) and other deposits are treated as an unsecured senior creditor claim. In the absence of a DIS, preference can be established by introducing a single tier for depositors, giving priority to deposit claims up to a certain limit in the hierarchy of creditor claims, with any deposits exceeding this limit being treated as unsecured senior creditor claims.

\section{BOX 2. Different Forms of Depositor Preference}

\section{WITHOUT}

(1) All deposits (with DIS subrogation to insured deposits) rank equally with other general unsecured claims.

\begin{abstract}
(2) Other general unsecured (including uninsured deposits and bondholders).
\end{abstract}

GENERAL
(2) Eligible deposits, ${ }^{2}$ exceeding the deposit insurance limit.
(3) Other general unsecured claims (including non-eligible deposits). $\begin{array}{ll}\text { (1) Insured deposits } & \text { (1) All deposits } \\ \text { (with DIS subrogation). } & \text { (with DIS subrogation). }\end{array}$

$\begin{array}{ll}\text { (1) Insured deposits } & \text { (1) All deposits } \\ \text { (with DIS subrogation). } & \text { (with DIS subrogation). }\end{array}$

Key: A higher position within each column and darker shading, indicates a more senior claim.

${ }^{1}$ Or in the absence of deposit insurance, deposit claims up to a certain limit.

2 Or in the absence of deposit insurance, deposit claims exceeding the limit.

- Tiered depositor preference, with two tiers, establishes a preference for insured deposits (and the DIS by means of subrogation) over uninsured eligible deposits, with a further preference of both categories over other senior unsecured, general creditors. ${ }^{14}$ In jurisdictions without a DIS, this form of preference can be established by giving priority to deposits up to certain amount, followed by another threshold for deposit claims above this limit, with the latter preferred over senior unsecured creditors.

13 For example, Switzerland, and Vietnam.

14 For example, the EU, Georgia, and Mexico. 
- General depositor preference gives preference to all deposit liabilities of a deposit-taking institution, regardless of their eligibility and coverage under the DIS, over other senior unsecured creditors. ${ }^{15}$ The DIS is subrogated for insured deposits and thus bears losses to the same degree as all deposits.

Recoveries by the DIS are a function of asset encumbrance and the type of preference given to deposits. Box 3 presents illustrative examples of distributions of recoveries for the DIS in the liquidation of two simple bank balance sheets (banks A and B), with these three forms of depositor preference in a jurisdiction with a DIS. These would be the recoveries that would accrue to preferred depositors in jurisdictions without DIS, under the different forms of depositor preference (single tier, tiered and general). They show that insured and tiered depositor preference provide most protection to the DIS or preferred depositors, while the tiered form also provides some protection to uninsured eligible deposits (i.e., retail deposits above the deposit insurance limit) to the disadvantage of other senior unsecured creditors (e.g., senior bondholders). Comparison of the distributions of losses for the DIS or preferred depositors for the two balance sheets (banks A and B) indicates that recoveries to the DIS decline significantly with asset encumbrance. Under insolvency law, secured creditors must be satisfied first from the proceeds of the encumbered asset. Where some creditors obtain a security interest on assets of the bank, this reduces the pool of assets available to satisfy all other creditors that rank below the secured creditors, and thus transfer losses to such creditors in a failure. Asset encumbrance typically increases at times of stress, when banks find it more difficult to raise unsecured funding.

\section{BOX 3. Creditor Recoveries Under Different Forms of Depositor Preference ${ }^{1}$}

\begin{tabular}{|c|c|c|c|c|c|}
\hline \multirow{2}{*}{ BANK A } & \multirow{2}{*}{ LIABILITIES } & \multicolumn{4}{|c|}{ RECOVERIES (AS \% OF CLAIM) } \\
\hline & & WITHOUT & INSURED & TIERED & GENERAL \\
\hline (a) Secured creditors & 20 & 100 & 100 & 100 & 100 \\
\hline $\begin{array}{l}\text { (b) Insured deposits } \\
\text { (DIS subrogated) }\end{array}$ & 50 & 75 & 100 & 100 & 100 \\
\hline (c) Uninsured deposits & 10 & 75 & 33 & 100 & 100 \\
\hline $\begin{array}{l}\text { (d) Other senior } \\
\text { unsecured creditors }\end{array}$ & 20 & 75 & 33 & 0 & 0 \\
\hline Total creditor claims & 100 & & & & \\
\hline \multirow{2}{*}{ BANK B } & \multirow{2}{*}{ LIABILITIES } & \multicolumn{4}{|c|}{ RECOVERIES (AS \% OF CLAIM) } \\
\hline & & WITHOUT & INSURED & TIERED & GENERAL \\
\hline (a) Secured creditors & 50 & 100 & 100 & 100 & 100 \\
\hline $\begin{array}{l}\text { (b) Insured deposits } \\
\text { (DIS subrogated) }\end{array}$ & 30 & 60 & 100 & 100 & 75 \\
\hline (c) Uninsured deposits & 10 & 60 & 0 & 0 & 75 \\
\hline $\begin{array}{l}\text { (d) Other senior } \\
\text { unsecured creditors }\end{array}$ & 10 & 60 & 0 & 0 & 0 \\
\hline Total creditor claims & 100 & & & & \\
\hline
\end{tabular}

The tables above show two different balance sheets, Bank A and Bank B, which enter liquidation after losses have eroded bank capital to zero, with remaining creditor claims totaling US $\$ 100$ and recoveries from the liquidation of assets of only US\$80 after losses in

15 For example, Malaysia, Philippines, and the United States. 
liquidation of US\$20. The DIS pays out insured deposits and substitutes in the place of insured depositors in terms of receiving liquidation proceeds of the failed bank's assets. Bank B has higher asset encumbrance i.e., higher secured, and lower senior unsecured liabilities.

Focusing on recoveries to the DIS only, the charts below model a higher loss of US\$50 for the same two banks A and B. The charts show the distribution of recoveries to the DIS for different forms of preference if losses are simulated as a normal distribution with a mean loss of US $\$ 50$ and a standard deviation of US $\$ 15$ (a normal distribution may underestimate losses in bank failures due to loss distributions with "fat tails"). The boxes show the lower quartile (25 percent) and upper quartiles (75 percent) of each distribution from 1,000 simulations; the lines (or whiskers) the minimum and maximum recoveries; and the data points the median recovery rates for the DIS. The results are identical for insured and tiered depositor preference as insured depositors (and the DIS subrogated) are ranked alone in second place in both hierarchies, with differences arising further down the hierarchy. These two forms of depositor preference provide most protection to the DIS, while the tiered form also provides some protection to uninsured eligible deposits (i.e., deposits above the deposit insurance limit) to the detriment of other senior unsecured creditors e.g., bond holders. Comparing the results for banks $A$ and $B$ show that recoveries to the DIS decline significantly as asset encumbrance increases.

Bank A: Distributions of DIS recoveries

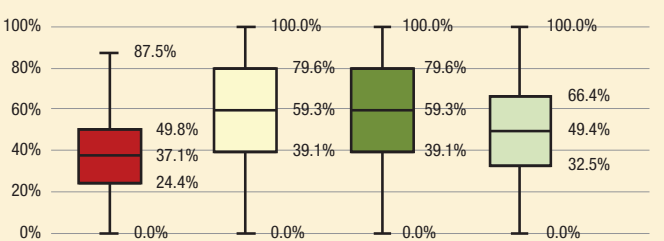

Bank B: Distributions of DIS recoveries

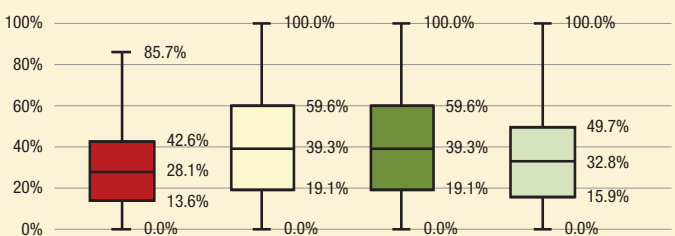

1 The conclusions reached in these examples with insured depositor preference are valid also for preferred depositors in a single-tiered or tiered preference in the absence of a DIS.

\section{CInternational Monetary Fund. Not for Redistribution}




\section{PROS AND CONS OF DEPOSITOR PREFERENCE}

Depositor preference affords financial stability advantages over ranking deposits pari passu with other senior unsecured creditors. Depositor preference provides at least three advantages, with their relative importance varying based on the specific type of depositor preference:

- Protecting financial stability with reduced costs. Depositor preference may facilitate a prompt resolution, protect the payment system, and reduce the overall possible costs to the DIS and the public, including the costs that may arise from the NCWOL compensation risks.

- Maximizing market discipline. By increasing their potential loss exposure, depositor preference provides incentives for other unsecured creditors (including bondholders) to monitor banks' risk-taking behavior more closely, and price their funding to banks accordingly. Depositor preference implicitly puts more of the weight in enforcing market discipline on financial investors (choosing between financial investments) than on firms and households using payment services. Another argument in favor of tiered or general depositor preference is that depositors with balances above the deposit insurance limit (households and nonfinancial firms) typically are less sophisticated, with less capacity to monitor bank risk than wholesale creditors (although the argument becomes weaker as depositors become larger). For depositor preference to impact on creditor incentives including to monitor risk, sufficient unsecured debt must remain and the risk that nonpreferred bank creditors incur losses in practice ought to be credible. Notwithstanding explicit legal provisions for loss sharing, if creditors expect to be bailed out (say, because the resolution framework is inadequate to deal with the failure of a systemic bank), the cost of bank liabilities will be mispriced (leading to too-big-to-fail premia).

- Cross-border cooperation. The lack of harmonized creditor hierarchy rules between jurisdictions, in particular with respect to the treatment of deposits, can impede cooperative approaches to resolving cross-border banks, as jurisdictions pursue national interests. Harmonization of creditor hierarchies through depositor preference-which does not discriminate between depositors based on the nationality of the depositors, the location of the deposit claim, or the jurisdiction in which the claim is payable would facilitate cooperationwould help to align incentives for cooperation across borders. Whereas for example, giving preference to the home jurisdiction's depositors over depositors in branches of the bank in foreign jurisdictions, could incentivize host authorities to protect local depositors e.g., ring fence.

The significant potential benefits of depositor preference need to be weighed against the potential impact on bank balance sheet structures and funding costs. By tilting the balance in favor of depositors, depositor preference increases the potential loss exposure of other unsecured creditors, which could impact the maturity, type and cost of this funding. Non-deposit creditors can take actions to better protect themselves such as collateralizing their claims, shortening the maturity, or increasing the cost of the funding (FSB, 2011) $)^{16}$ :

- Impact on bank wholesale funding. Introducing depositor preference would, ceteris paribus, increase the risk and, accordingly, the potential cost of accessing unsecured wholesale funding by affecting the payoff received in a potential bank failure. In the longer run, the likely

16 There is extensive literature on deposit insurance generating moral hazard risk (see for example Demirgüç-Kunt et al. 2003). With depositor preference, however, risks are transferred from one to another set of creditors of the failed bank, without necessarily increasing moral hazard risks.

Technical Notes and Manuals 2020/002 
reduction in the cost of deposit funding may mitigate the overall impact on bank funding costs. In the short term introducing depositor preference could have a significant impact on banks already facing market funding strains.

- Increased reliance on secured funding and encumbrance of assets. Creditors may seek to protect themselves by securing collateral, for example, through covered bonds. Increased encumbrance of bank assets will limit resolution options and potentially result in higher costs and negatively impact creditors holding unsecured claims (e.g., depositors).

- Regulatory arbitrage. Banks may restructure liabilities, for instance, by creating deposit-like instruments, so that creditors secure protection under depositor preference. Also, to the extent that some classes of senior liabilities may be exempt in resolution from bail-in (e.g., very shortterm liabilities or derivative claims), unsecured creditors may seek to attenuate their risk of loss and still satisfy their demand for bank risk exposure via financial engineering or informal agreement (e.g., committing to continuously roll over short-term liabilities).

The impact of introducing depositor preference on overall bank funding costs will be context specific. From a review of various studies, Hardy (2013) concludes that introducing depositor preference in the US had "little "systemic effect" on overall bank funding costs. A more recent study (Danisewicz et al. 2018) looked at its staggered introduction across US states. It found that depositor preference led to a decline in uninsured deposit rates and an increase in nondeposit rates (widening the spread between the two), while also improving banks soundness as bank risk and leverage declined. This is consistent with theoretical work suggesting that depositor preference enhances monitoring by nonpreferred creditors, ${ }^{17}$ which are better placed than retail depositors to monitor bank risk-taking. Staff analysis of the introduction of tiered depositor preference in the European Union (EU) found that the spread between bank bonds and deposit rates widened (Appendix I). Data for four EU member-countries (Germany, the Netherlands, Spain, and the United Kingdom) that previously did not have depositor preference showed an increase of between 40 and 70 basis points of the spread of senior bond prices (as proxied by credit swap spreads) to deposit rates. As this change was driven primarily by a decline in deposit rates rather than higher bond rates, the data would suggest that introducing depositor preference did not increase overall funding costs of the (large) banks in the study. Given the challenges of isolating the impact of depositor preference from contemporaneous events, including the strengthening of capital and liquidity supervision and quantitative easing, however, these findings cannot be generalized. Depending on country specific circumstances, for example in banking systems already facing funding stress, introducing depositor preference could prove destabilizing in the short term. This would advocate for delaying the introduction of depositor preference until a later, more stable time.

Regulatory measures may also be needed to mitigate unintended effects. Were the introduction of depositor preference to lead to non-preferred creditors increasingly collateralizing or shortening their exposures, obligatory minima for unsecured debt over a certain maturity which could be bailed-in in a resolution, and/or limits on the encumbrance of bank balance sheets may need to be introduced. In doing so the authorities should consider the trade-offs in terms of the impact on bank intermediation costs versus the financial stability benefits.

17 Since depositor preference subordinates non-depositor claims, these creditors monitor risks taken by the bank more intensively because of the greater losses they face in the event of its failure. 


\section{COUNTRY EXPERIENCE AND LESSONS}

While most FSB member countries have established depositor preference, the practice is not universal. Most FSB jurisdictions, some as part of reforms introduced after the global financial crisis (including in the European Union-Box 4), afford preferential treatment to at least some depositors. ${ }^{18}$ Outside of FSB membership, however, depositor preference is not yet universal.

\section{BOX 4. Deposit Preference in the European Union}

The Bank Recovery and Resolution Directive (BRRD) ${ }^{1}$ introduced two-tiered depositor preference across the European Union. Article 108 provided for a higher priority ranking among unsecured claims for deposits up to the coverage level under the DIS, followed by a second priority ranking for eligible deposits exceeding the coverage level held by natural persons, and micro, small-, and medium-sized enterprises. Large corporate deposits rank below, typically pari passu, with other claims of general unsecured creditors, such as senior bondholders. ${ }^{2}$ In the 2018 in the recent Euro Area FSAP Fund staff recommended that a general depositor preference also be introduced. This could be achieved by means of adding a third tier consisting of all other deposits to the EU's tiered depositor preference regime. Staff argued that a third tier for deposits ineligible for deposit insurance coverage (including deposits from public authorities and pension funds) would facilitate resolution and reduce the risk of compensation claims if bondholders were bailed in.

1 https://eur-lex.europa.eu/legal-content/EN/TXT/PDF/?uri=CELEX:32014L0059\&from=EN

2 Recent amendments to Article 108 of the BRRD introduced a new asset class of "nonpreferred" senior debt instruments, [https://eur-lex.europa.eu/legal-content/EN/TXT/PDF/?uri=CELEX:32017L2399\&from=DE.]

A review of cross-country legislation shows no clear relationship between the existence of deposit insurance and the existence and type of depositor preference. Many countries with a DIS also provide for depositor preference. In contrast, some countries (e.g., Japan and South Korea) have a DIS but do not have depositor preference, whereas some others provide for depositor preference in the absence of a DIS (e.g., Panama and Zambia). Also, countries with depositor preference take different approaches on their relative ranking to other preferred claims, such as tax and employee remuneration claims. Such preferential claims are often paid prior to senior unsecured claims, including where depositor preference has been established. In a few cases, however, the priority granted to (insured) deposits ranks ahead of tax (e.g., Qatar) as well as social security claims (including in Lithuania and Peru).

The provisions for depositor preference and deposit insurance should be coordinated. Jurisdictions that establish preference for DIS claims, should establish it also for insured deposits. Some jurisdictions only give preference to DIS claims, presumably based on the assumption that insured deposits will be paid out by the DIS, as would be the case in liquidation. However, problems could arise in the application of resolution tools (such as bail-in and purchase and assumption or

18 Argentina, Australia, China, India, Indonesia, Mexico, Russia, Turkey, the United States, and the EU member states; also, Hong Kong SAR, Singapore, and Switzerland. However, Canada, Japan, and South Korea do not have depositor preference. In some other countries (e.g., South Africa), reforms to introduce deposit preference are underway. 
P\&A) in which no DIS payouts are made. To mitigate this risk, depositor preference for insured deposits should be established with the stipulation that the DIS be subrogated to these claims for the funding it provides to support such deposit claims in a resolution. Some jurisdictions set in their laws the ceiling for depositor preference differently from the deposit insurance coverage. ${ }^{19}$ However, if tiered depositor preference is introduced, it is advisable to link the ceiling to the level of deposit insurance coverage in a way that allows the ceiling to increase over time together with insurance coverage ${ }^{20}$ Additionally, where the applicable ceiling is disproportionally low and there is no separate preference applicable to the DIS, the DIS will rank pari passu with other senior unsecured creditors for a portion of its claims, which could put public resources at risk.

Related party deposits are typically treated as exceptions. Jurisdictions with a deposit insurance typically consider certain related-party deposits as ineligible for insurance. ${ }^{21}$ This prevents such related party deposits from receiving a preferential treatment with insured or eligible deposits, which otherwise would raise moral hazard issues. Some jurisdictions with DIS have specifically subordinated such related party to general unsecured creditors (e.g., Moldova and Tajikistan). Jurisdictions without a DIS should include adequate provisions to address this moral hazard concern, especially as the bank's failure may be attributed to such related parties.

19 For example, in Argentina and India.

20 This approach is followed in Afghanistan, Mexico, and Moldova, for example.

21 IADI Core Principle 8, Essential Criteria 2 allows such exclusions that are clearly specified, easily determined and do not affect the speed of reimbursements. 


\title{
VI. GENERAL RECOMMENDATIONS
}

\begin{abstract}
Adoption of depositor preference should be informed by an assessment of the potential impact. "Jurisdictions considering introducing depositor preference, or changing their existing depositor preference arrangements, should weigh the advantages and disadvantages in the context of their legal and judicial framework and financial system structure", (IADI 2014). Issues to consider include the potential impact on different unsecured funding sources and their costs, the differing role of uninsured deposits (i.e., their importance in the payment system as working capital versus financial investments), and the ability of institutions to absorb potential changes in funding structures. In the long run, altering creditor hierarchies might not significantly change average bank funding costs (e.g., higher costs for less preferred, unsecured funding might be offset by lower costs for deposits). However, in the short term, the higher cost or reduced availability of wholesale funding may exacerbate vulnerabilities if introduced at times of stress, particularly for weak institutions susceptible to a "flight to quality."
\end{abstract}

Staff normally recommends either tiered or general deposit preference. In providing advice on bank resolution frameworks, staff typically addresses the issue of creditor hierarchy of banks explicitly, and advocates for the specific type of depositor preference depending on country circumstances, including whether a DIS is in place (Box 5). Insured and tiered depositor preferences offer the most protection to the DIS or to the state. Insured depositor preference may provide insufficient depositor protection when the level of deposit insurance coverage is low, or where small- and medium- sized enterprise (SME) deposits are not eligible for protection. General deposit preference would offer advantages in circumstances where all deposits, including those that are ineligible for deposit insurance coverage, may need to be protected. General deposit preference would also facilitate a greater contribution from the DIS to resolution (the flipside of the DIS being better protected under insured and tiered depositor preference).

\section{BOX 5. Relative Advantages and Disadvantages of Different Forms of Deposit Preference}

\section{INSURED GENERAL TIERED}

Enhance depositor confidence and reduce contagion

Facilitate a resolution in which all deposits are protected

Reduce the costs of bank failures to the DIS and/or state

Protect payment system and economic activity

Maximize market discipline for wholesale creditors

$\begin{array}{ccc}+ & +++ & ++ \\ + & +++ & ++ \\ ++ & + & ++ \\ + & +++ & ++ \\ + & ++ & ++\end{array}$

National depositor preference should be avoided. Differences in creditor hierarchies can produce unequal treatment and distort incentives for cross-border coordination. Discrimination against depositors in foreign branches may diminish the willingness of national authorities to cooperate. In this regard, it is of crucial importance that national resolution regimes do not discriminate against foreign depositors through a national depositor preference rule. 
In the absence of a DIS, it is necessary to support depositor preference with advance payment rules. When a DIS exists, it should promptly pay out insured deposits in a liquidation. However, when there is no DIS, empowering the liquidator to make advance payments to depositors can be of critical importance to prevent depositors losing confidence. These advance payments would allow depositors to withdraw limited amounts, subject to available liquidity.22 Advance payments might be achieved more readily, as scarce liquidity would not need to be allocated on a pro rata basis across a wider set of creditor claims, in a single-tiered depositor preference system.

In any event, depositor preference is a complement of, not a substitute for, deposit insurance and is typically recommended as part of a range of financial-safety-net reforms. Without effective mechanisms to ensure the continuity of a bank's critical functions and the quick reimbursement of insured deposits, depositor preference alone will most likely be insufficient to mitigate the risk of depositor contagion. Therefore, staff typically recommends depositor preference as one of several measures to enhance a countries' financial stability net, including introducing a DIS when the right conditions are in place. ${ }^{23}$

22 See Panama.

23 Including a sound financial sector structure; effective prudential regulation, supervision, and bank resolution; strong legal, and judicial frameworks; and accounting and disclosure systems. 


\title{
APPENDIX 1. THE EVOLUTION OF SENIOR DEBT-DEPOSIT SPREAD FOLLOWING THE INTRODUCTION OF DEPOSITOR PREFERENCE IN THE EUROPEAN UNION
}

\author{
Introduction
}

The BRRD introduced two-tiered depositor preference across the European Union. Article 108 of the BRRD provided for a higher priority ranking among unsecured claims for deposits up to the coverage level under the Deposit Guarantee Scheme (DGS), followed by a second priority ranking for eligible deposits exceeding the coverage level held by natural persons, and micro- and SMEs. The DGS Directive provides for the DGS being subrogated to the rights and obligations of covered depositors. Large corporate deposits rank below eligible deposits, typically pari passu, with other claims of general unsecured creditors (such as senior bondholders).

By changing the insolvency creditor hierarchy, the introduction of depositor preference may alter the relative cost of senior unsecured debt vis-à-vis bank deposits of individuals and SMEs. The new rank ordering in creditor claims implies a relatively higher severity of loss in resolution for senior unsecured debt instruments, because these will no longer benefit from their previous pari passu status with eligible deposits. For deposits (excluding deposits held by large corporations), the legislation implies a relatively lower severity of loss as these will benefit from the subordination of long-term debt instruments. As member countries passed legislation to transpose the BRRD (and, hence, introduce depositor preference), markets in those countries may price-in the change in risk to the price of senior unsecured debt (mainly banks' senior bonds) and deposit rates. This could potentially change the relative bank funding costs, depending on the extent to which higher cost of (now less-preferred) unsecured debt is offset by lower costs of (now more-preferred) deposits.

This appendix analyzes the evolution of banks' funding costs- the spread between bank deposit rates and senior bond prices in four EU countries following the introduction of depositor preference. The BRRD was officially adopted in May 2014 and entered into force in July 2014, with a deadline to implement the BRRD provisions legislation into national law as of January 1, 2015 (bail-in provisions by January 1, 2016). The analysis focuses on four countries-Germany, the Netherlands, Spain, and the United Kingdom—where neither depositor preference nor DGS preference existed before the BRRD. ${ }^{24}$ National legislation to implement the full BRRD provisions (including bail in) were passed in German and the United Kingdom in January 2015, and in the Netherlands and Spain in November 2015 and January 2016, respectively (Figure 1).

24 ISDA BRRD Implementation Monitor (5th edition). 
FIGURE 1. Timeline of BRRD-related regulatory events from 2014-2017 in select EU countries

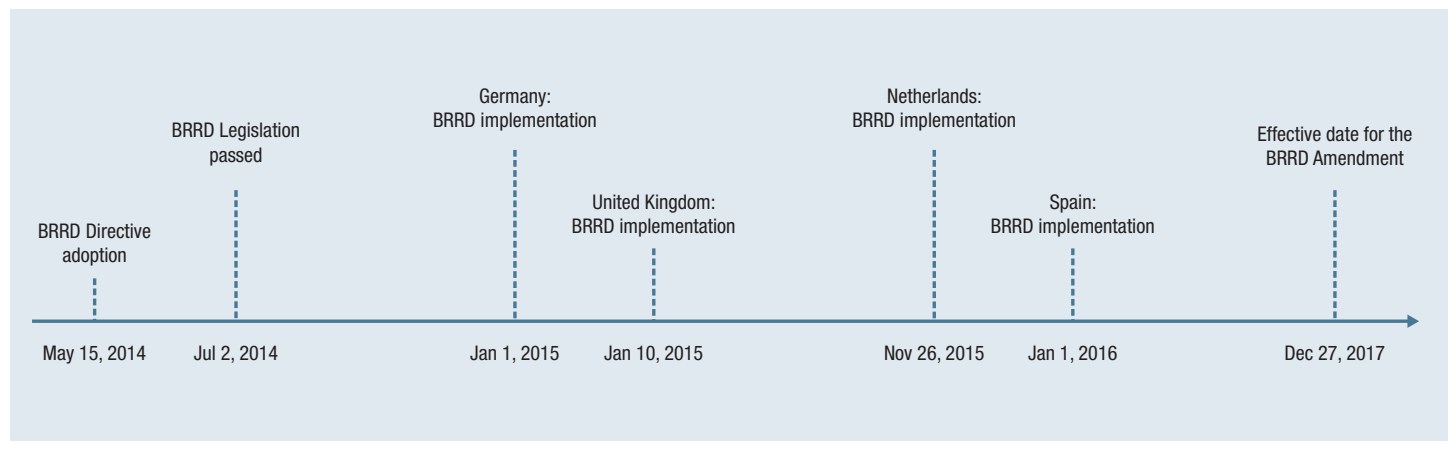

Source: ISDA BRRD Implementation Monitor (5th edition), central banks' website, news reports.

Notes: According to Article 108 of the BRRD, unsecured deposits of SMEs and natural persons are ranked ahead of other liabilities. The BRRD amendments aim to harmonize the hierarchy of creditor claims in bank insolvency.

\section{Data}

Deposit rates declined during the sample period from January 2013 to January 2018 (Figure 2). Due to unavailability of bank-specific deposit rates, the study uses the average system-wide monthly bank deposit rates published by central banks. It only considers the deposit rates for households, since the deposits of large corporations were not preferred and ranked pari passu with senior debt. The analysis uses the 'two years or more' deposit rates, the maximum period available, for comparability to the two- and five-year senior bond maturities (repeating the analysis with shorter rates does not significantly change the results). Deposit rates generally followed the ECB policy rates (the deposit facility rate and the refinancing rate), which were lowered steadily during the period. The ECB deposit facility rate was brought down to zero in July 2012 and became negative for the first time in June 2014. While bank deposit rates for households and nonfinancial corporations declined consistently during this period; they did not enter negative territory.

The study uses CDS spreads (Figure 3) instead of bond rates for several reasons. These include the difficulty of aggregating bond price changes when the period of the analysis extends beyond the maturity of individual bonds. CDS spreads offer a continuous and clean measure of risk of default, and empirical studies ${ }^{25}$ have shown that they are more liquid and lead bond markets in price discovery. The study calculates CDS swap rates for the top five banks by total assets (as of January 2016) in the four EU countries in the sample, with outstanding two- and five-year senior bonds between 2012 and 2018. It uses the month-end value of senior bond CDS spreads (reported in basis points) to compute the spread between CDS and deposit rates from January 2013 to January 2018.

\section{Methodology}

The CDS-deposit spread is calculated as the difference between the weighted average CDS of the top five banks and the deposit rate for each country. The weights applied to the bank-level CDS are calculated using the sum of total assets of the top five banks in each EU member country.

25 Daniels and Jensen (2005), Zhu (2006), Bessembinder et al. (2009). 
The monthly series CDS-deposit spread from January 2013 to January $2018^{26}$ is split into periods before and after, based on the month in which the BRRD legislation was enacted in national legislation. For each country, the start date is chosen to include at least two years before the BRRD legislation deadline. The end date is chosen to exclude the months after the BRRD Amendment, which aims to harmonize the hierarchy of creditor claims in bank insolvency across the EU countries (for creditors ranking below preferred deposits). We test for difference in means of the spread in the before and after periods for each country's CDS-deposit spread. Assuming equal variance, we test for differences in means of the spread, using a t-test, where the null hypothesis is that the difference between the before spread and the after spread is greater than or equal to 0 , and the alternative hypothesis is that the difference between the before spread and the after spread is less than 0 . The spread is the weighted two-year senior bond CDS of top five banks, minus the two years or more deposit rate for households. Thus, if the t-test rejects the null hypothesis $\mathrm{H}_{\mathrm{O}}$ against the alternative hypothesis $\mathrm{H}_{\mathrm{A}}$, it implies that the after spread is greater than the before spread.

$$
\begin{aligned}
& H_{O}: \overline{\text { Spread }}_{\text {before }}-\overline{\text { Spread }}_{\text {after }} \geq 0 \\
& H_{A}: \overline{\text { Spread }}_{\text {before }}-\overline{\text { Spread }}_{\text {after }}<0
\end{aligned}
$$

\section{FIGURE 2. Monthly deposit rates in select EU countries from 2013-2017 (in bps, for over-two-years deposits)}

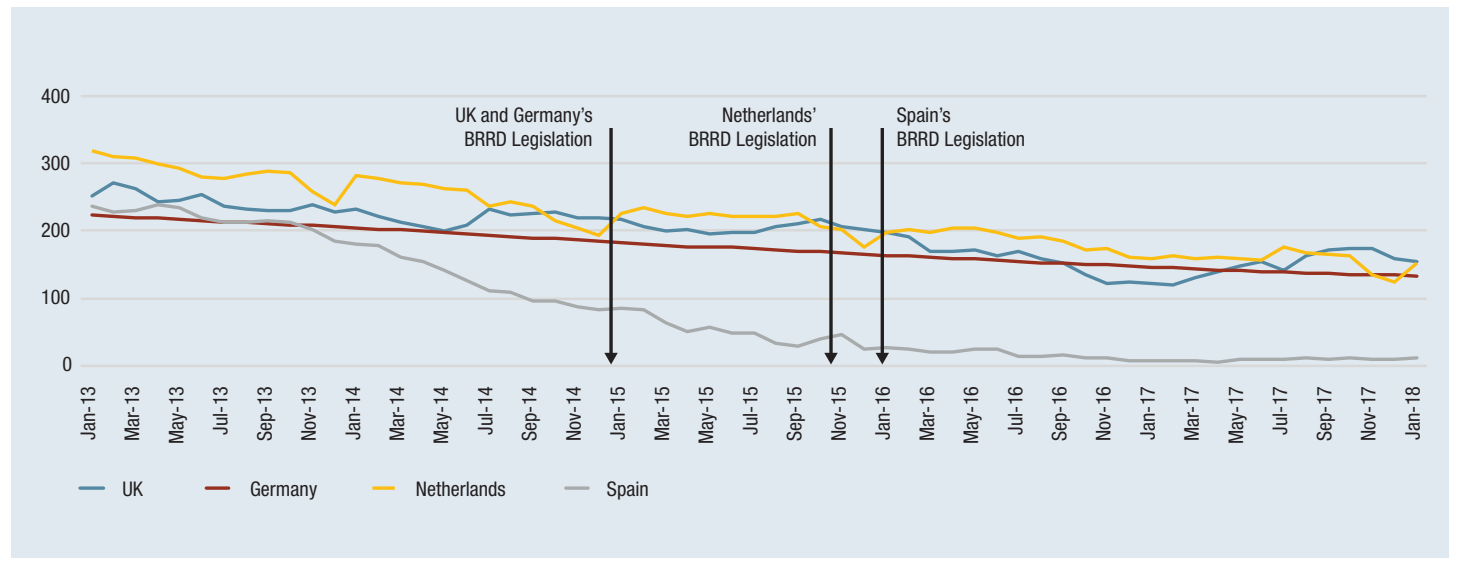

Source: Haver, central banks' website

Note: Deposits of large corporations rank below eligible deposits, typically pari passu with other claims of general unsecured creditors (senior bondholders). DP-related legislations: For UK and Germany: January 2015, the Netherlands: November 2015, and for Spain: January 2016

26 The start date is constrained by the CDS data availability for all banks in the sample for each country. For the United Kingdom (January 2013 through January 2018), Germany (January 2013 through January 2018), the Netherlands (April 2013 through January 2018), and Spain (June 2014 through January 2018). 
FIGURE 3. Month-end weighted CDS of top five banks in select EU countries from 2013-2017 (in bps, two-year senior bond CDS)

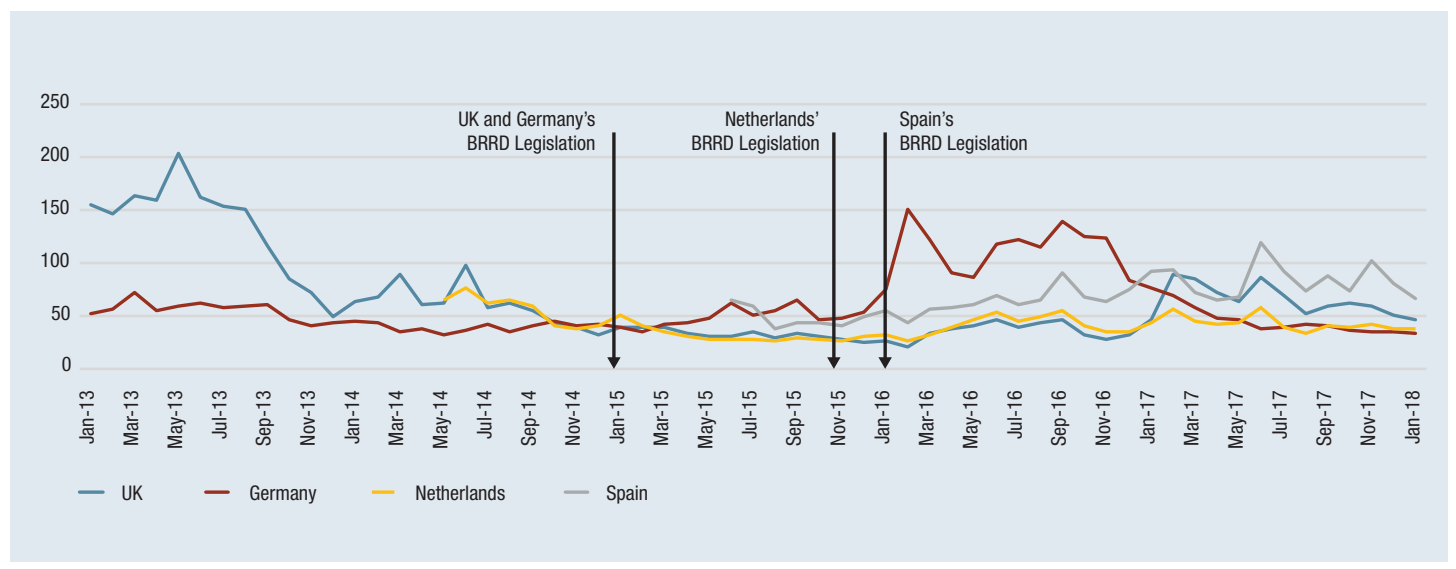

Sources: Bloomberg (CDS series for banks), staff calculations

Note: The weighted CDS corressponds to top five senior bond issuing banks, by total assets as of January 2016, in each EU country, and the series are constructed starting from the date all data become available for a country. The weighted CDS series for the Netherlands and Spain start in May 2013 and June 2014, respectively, due to the unavailability of the CDS series for a subset of the top banks before these dates.

\section{Results}

The CDS-deposit spread increased for all the countries in the sample (see Figure 4). From the point of the transposition of the BRRD into national law, the CDS-deposit rate spread exhibits an upward trend in all the countries in the sample. The CDS-deposit spread increase is primarily driven by declining deposit rates (Table 1). Using two-year and five-year CDS, the null hypothesis is strongly rejected for all countries, implying that the mean spread of the after period is higher than the mean spread of the before period. Using two-year CDS (see Table 1, Panel A), the change in CDS is small, except for a slight increase in CDS for German banks. Using five-year CDS (see Table 1, Panel B), the change in CDS is, negative for all countries. Moreover, most of the change in the spread can be attributed to the declining deposit rates. The results suggest, however, that there was no significant increase in banks' relative funding costs following the introduction of depositor preference. Deposit rates decreased in the post-BRRD legislation period, while the weighted CDS increased slightly and returned to pre-BRRD levels toward end-2017. 
TABLE 1. Testing for difference in spread before and after the BRRD legislation (All values in basis points)

\begin{tabular}{|c|c|c|c|c|c|c|c|c|c|c|c|c|}
\hline \multirow[b]{2}{*}{ COUNTRY } & \multicolumn{4}{|c|}{ MEAN OF WEIGHTED-CDS } & \multicolumn{4}{|c|}{ MEAN OF DEPOSIT RATE } & \multicolumn{4}{|c|}{ MEAN OF SPREAD } \\
\hline & BEFORE & AFTER & $\Delta$ & (T-STAT) & BEFORE & AFTER & $\Delta$ & (T-STAT) & BEFORE & AFTER & $\Delta$ & (T-STAT) \\
\hline Germany & 47 & 68 & 21 & $(-2.9)$ & 205 & 156 & -49 & (13.3) & -158 & -87 & 70 & $(-9)$ \\
\hline United Kingdom & 46 & 42 & -4 & (0.8) & 232 & 171 & -60 & (9) & -185 & -129 & 56 & $(-7)$ \\
\hline Netherlands & 41 & 32 & -9 & (2.4) & 245 & 173 & -72 & (10.3) & -203 & -140 & 63 & $(-11)$ \\
\hline Spain & 58 & 61 & 4 & $(-0.5)$ & 69 & 13 & -57 & (9.1) & -20 & 22 & 42 & $(-7)$ \\
\hline
\end{tabular}

Panel B. Using five-year CDS

\begin{tabular}{lccccccccccccc} 
& \multicolumn{3}{c}{ MEAN OF WEIGHTED-CDS } & \multicolumn{3}{c}{ MEAN OF DEPOSIT RATE } & \multicolumn{3}{c}{ MEAN OF SPREAD } \\
\hline Country & BEFORE & AFTER & $\Delta$ & (T-STAT) & BEFORE & AFTER & $\Delta$ & (T-STAT) & BEFORE & AFTER & $\Delta$ & (T-STAT) \\
\hline Germany & 108 & 92 & -16 & $(2)$ & 215 & 151 & -65 & $(16.1)$ & -92 & -51 & 41 & $(-5.1)$ \\
United Kingdom & 161 & 112 & -50 & $(6)$ & 264 & 172 & -92 & $(10.3)$ & -103 & -61 & 42 & $(-6.8)$ \\
Netherlands & 80 & 54 & -26 & $(4.8)$ & 245 & 166 & -79 & $(12.1)$ & -165 & -112 & 53 & $(-12.6)$ \\
Spain & 115 & 112 & -3 & $(0.3)$ & 69 & 12 & -57 & $(10.5)$ & 46 & 99 & 54 & $(-4)$
\end{tabular}

Sources: Bloomberg, Haver, and IMF staff calculations

Notes: The change $(\Delta)$ is equal to the difference between the before and after mean weighted CDS. Mean spread is the difference of the two-year (or five-year) weighted-CDS measure and over-two-years deposit rate for households. The CDS measure is the weighted average of the two-year senior bond CDS of the top five banks for each country. The null hypothesis is that the difference between the before spread and the after spread is greater than or equal to 0 . If the $\mid t$-statistic $K$ $\mathrm{t}$-critical, (less than 1.68), the null hypothesis is rejected, i.e., the after spread is greater than the before spread.

Event study analysis tests were used to assess the degree to which the results were driven by monetary policy. We compute abnormal spread, as well as the abnormal CDS and abnormal deposit rate. The abnormal level of a variable is the difference between the observed and the expected value. The observed values are the monthly values of the spread (or CDS or deposit rate) in the post-BRRD period (observation period). In the mean-adjusted approach, the expected value is the mean of the values in the pre-BRRD period (estimation period). In the market-adjusted approach, we obtain regression coefficients from a one-factor or two-factor regression model based on the estimation period data, controlling for monetary policy and stock market variables, and use the coefficients to compute the fitted spread (or CDS or deposit rate) in the observation period. The main findings from the mean-adjusted and market-adjusted event study analyses are as follows:

- Computing the abnormal spread using the mean-adjusted approach is equivalent to testing differences in means. The results remain the same as depicted in Figure 4.

- For the market-adjusted approach, we estimate a one-factor model (accounting for the sovereign bond yield for each country) and a two-factor model (accounting for the sovereign bond yield and the stock market volatility index for Europe (VSTOXX)). ${ }^{27}$ Except for Germany, we find that the abnormal spread tends to follow the abnormal deposit rates, and the abnormal CDS is statistically insignificant. We plot the negative of the abnormal deposit rates in Figure 5. To the extent that the monetary policy rate 28 and stock market volatility account for policy changes and market developments in the event-study analyses, we find evidence of an increase in the CDS-deposit rate spread, driven by declining deposit rates but not by increasing CDS.

27 Estimating using the country-specific inflation rate and stock market indices did not have explanatory power.

28 Proxied by the sovereign bond yield for each country. 
- The deposit to liabilities ratio of the banking sector in the sample countries do not exhibit significant variation over the sample period. We check for significant changes in the composition of bank funding across the sample period and do not find evidence suggesting the banks in these countries adjusted their ratio of deposit funding to total liabilities, relative to the period before depositor preference was introduced (Figure 6).

\section{Data and Methodology Limitations}

The unavailability of bank-specific deposit rates and the data related to uninsured deposits at banks are significant limitations. Given these data constraints, it is not possible to study changes in the volume of uninsured deposits (greater than EUR 100,000) or compute a bank-specific spread. Moreover, dependence on wholesale vis-à-vis deposits can vary across banks as well across countries, and we are not able to account for differences in the substitutability of senior bonds and uninsured deposits. We account for country-level monetary policy changes and stock market volatility in Europe, but we can't account for bank-level risk factors that affect deposit rates and bond prices, such as asset quality, returns, volatility, liquidity and capital, and changes in credit ratings. While we restrict the sample period to exclude the period when the BRRD Amendment became effective, we ignore other legislative changes, both before and after the transposition of the BRRD. Finally, we use the largest banks for data reasons and, therefore, do not account for too-big-to-fail premia.

\section{FIGURE 4. Spread of CDS and deposit rates for banks in select EU countries from 2013-2017 (in bps, weighted two-year senior bond CDS, over-two-years deposit rate)}

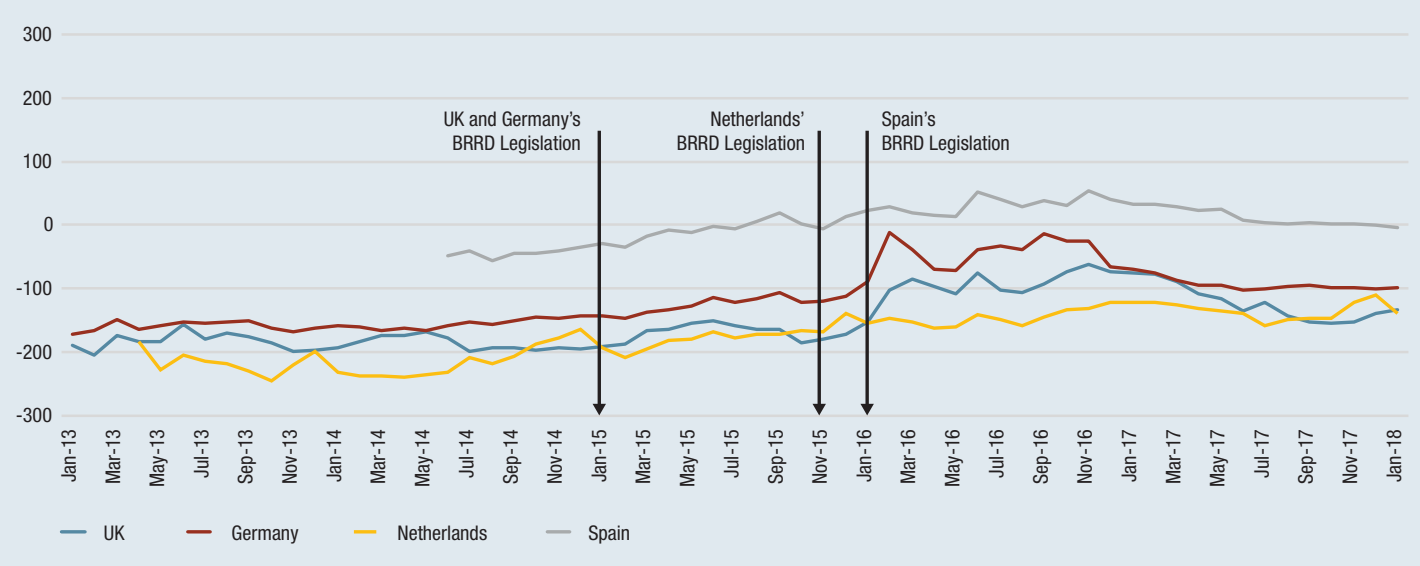

Sources: Bloomberg (CDS series for banks), Haver and IMF staff calculations

Note: The weighted-CDS measure corresponds to top five senior-bond-issuing banks of the country, by total assets, as of January 2016. The weighted CDS series for the Netherlands and Spain start in May 2013 and June 2014, respectively, due to the unavailability of the CDS series for a subset of the top banks before these dates. 


\section{FIGURE 5. Event-study analysis using market- and monetary policy-adjusted approach (All values in basis points)}

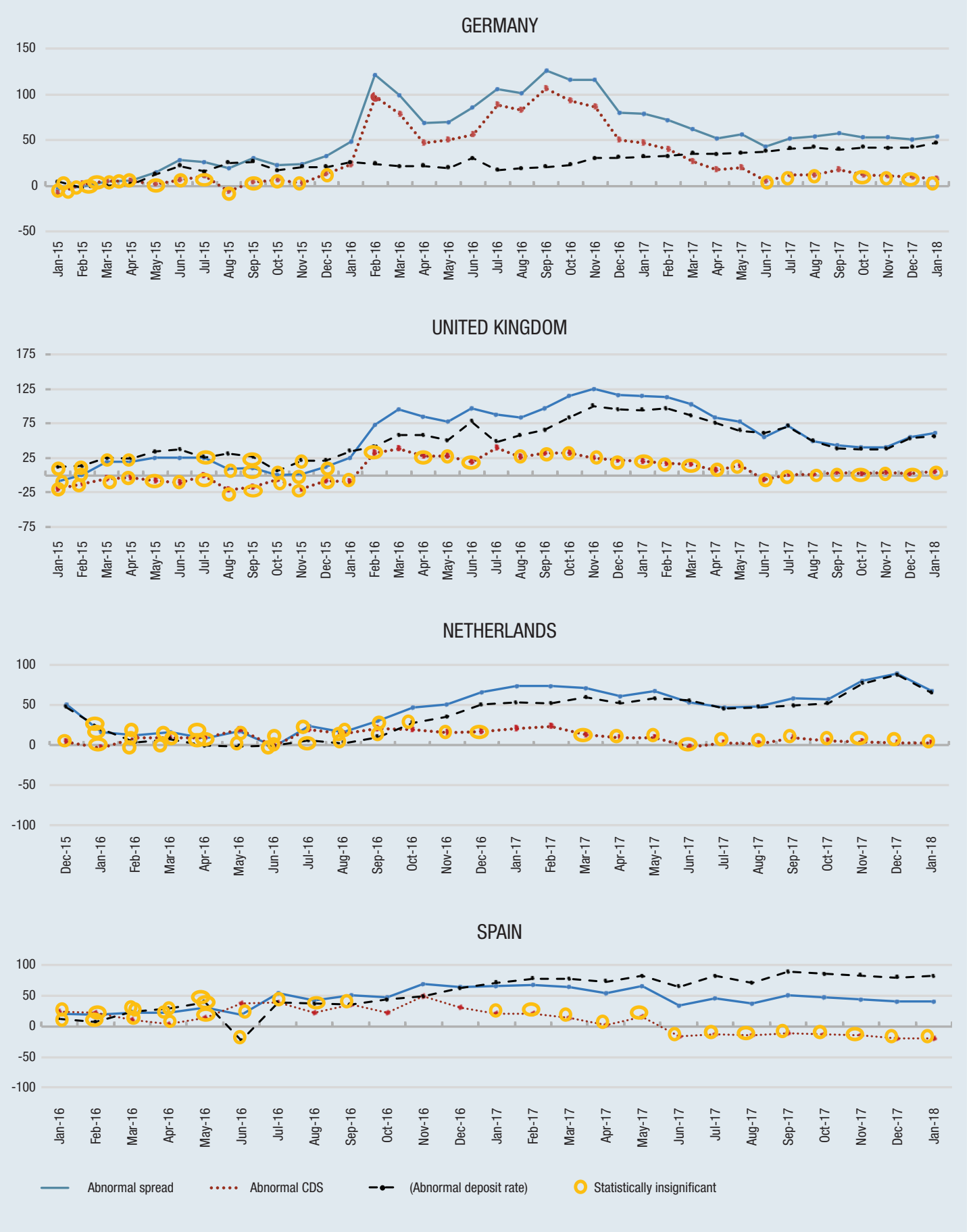

Sources: Bloomberg, Haver, and IMF staff calculations

Notes: The abnormal spread is calculated based on a two-factor event study model, which accounts for the sovereign bond yield (10-year government bond of each country) and the European stock market volatility index- VSTOXX. The same model is used to compute abnormal CDS and abnormal deposit rate. The pre-BRRD transposition period is the estimation period for each country, and the post-BRRD transposition period is the observation period for the study. The definition of spread, CDS and deposit rates are same as before. Statistical significance is determined at the 5 percent level of significance. 
FIGURE 6. Deposit to liabilities ratio for monetary financial institutions (MFIs) in select EU countries (end of period, seasonally unadjusted values, excl. the Eurosystem)

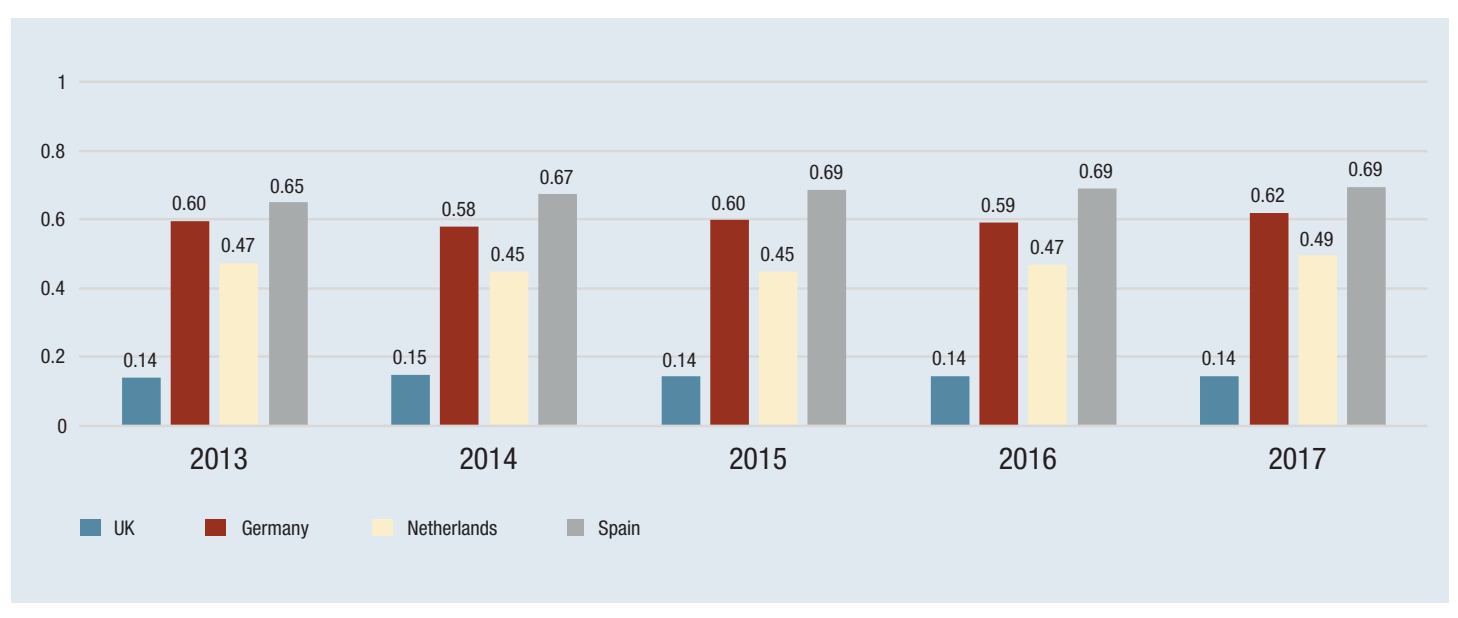

Source: Haver (Aggregated Balance Sheets of MFIs)

Notes: End of period data on deposits and liabilities are for the Euro Area. Per EU law, MFIs are resident credit institutions which can receive deposits, grant credits and make investments in securities. The Eurosystem comprises the ECB and the national central banks of the Eurozone countries. 


\section{REFERENCES}

Dang, Tri Vi, Gary Gorton, Bengt Holmström, and Guillermo Ordoñez. 2017, "Banks as Secret Keepers," American Economic Review, 107 (4): 1005-29.

Danisewicz, Piotr, Danny McGowan, Enrico Onali, and Klaus Schaeck, Debt Priority Structure, Market Discipline, and Bank Conduct, The Review of Financial Studies, Volume 31, Issue 11, November 2018.

Davies, Geoffrey and Marc Dobler, 2011, Bank resolution and safeguarding the creditors left behind, Bank of England Quarterly Bulletin (Q3).

Demirgüç-Kunt, Asli, and Harry Huizinga, 2003, "Market Discipline and Deposit Insurance," Journal of Monetary Economics 51(2), pp. 375-399.

Despina, Christofi, 2018, Effective judicial protection of bank depositors during the financial crisis and arbitration in an EU context, Doctoral thesis, University of Central Lancashire.

Financial Stability Board, 2011, Effective Resolution of Systemically Important Financial Institutions, FSB Consultative Document, July.

Geva, Benjamin, 2001, "Bank Collections and Payment Transactions: A Comparative Legal Analysis," Oxford Scholarship Online.

Hardy, Daniel, 2013, Bank Resolution Costs, Depositor Preference and Asset Encumbrance, International Monetary Fund Working Paper 13/172.

International Monetary Fund (IMF), 2014, "Cross-Border Bank Resolution: Recent Developments," (Washington: International Monetary Fund).

International Monetary Fund (IMF), 2018, Euro Area Policies, Financial Sector Assessment Program, Technical Note-Bank Resolution and Crisis Management.

Hirschhorn, Eric, and David Zervos, 1990, Policies to change the priority of claimants: The case of depositor preference laws, Journal of Financial Services Research.

International Association of Deposit Insurers (IADI), 2014, "Core Principles for Effective Deposit Insurance Systems."

Kaufman, George G., 1997, The New Depositor Preference Act: Time Inconsistency in Action, Managerial Finance.

Laurinavicius, Kestutis, 2006, The Legal Nature of Bank Deposits, 31(3):291-330 Review of Central and East European Law.

Lenihan, Niall J., Maike B. Luedersen, and Martin Schulte, The hierarchy of creditor claims in bank insolvency-Recent developments and the advisory functions of the European Central Bank, Revue de Droit Bancaire et Financier, 2016/VI.

Marino, James A., and Rosalind L. Bennett, 1999, The Consequences of National Depositor Preference, FDIC Banking Review.

UNCITRAL, (2005), Legislative Guide on Insolvency Law. 
International Monetary Fund

Monetary and Capital Markets

700 19th Street NW

Washington, DC 20431

USA

T. $+(1) 202.623 .8554$

F. + (1) 202.623.6073

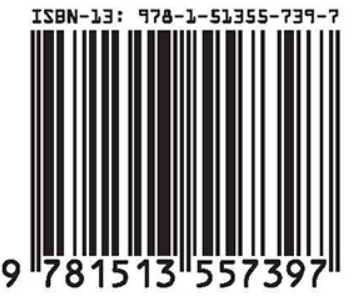

